TEME, г. XUI, бр. 1, јануар - март 2018, стр. 167-184

Оригинални научни рад

DOI: 10.22190/TEME1801167S

Примљено: 4. 7. 2017.

Одобрено за штампу: 12. 3. 2018.

UDK 657.6(497.11+497.4)

\title{
INTANGIBLE ASSETS IN THE CONSOLIDATED FINANCIAL STATEMENTS OF SERBIAN AND SLOVENIAN LISTED COMPANIES: A PRELIMINARY OVERVIEW OF THE REPORTING PRACTICES
}

\author{
Dejan Spasić ${ }^{1 *}$, Anton Vorina ${ }^{2}$ \\ ${ }^{1}$ University of Niš, Faculty of Economics, Niš, Serbia \\ ${ }^{2}$ School of Economics, Vocational College, Celje, Slovenia \\ *dejan.spasic@eknfak.ni.ac.rs
}

\begin{abstract}
The aim of the research is to achieve a conclusion what is the level of the reporting practice on intangible assets in two countries - in the Republic of Serbia and in the Republic of Slovenia trough a comparative descriptive statistics. Consolidated financial statements of listed companies in these two countries were used from the Belgrade Stock Exchange (Serbia) and the Ljubljana Stock Exchange (Slovenia). The reason for the use of consolidated financial statements lies in the fact that they can contain unconsolidated intangible assets already recognized in the separate financial statements of the companies included in the group, as well as internally generated intangible assets that meet the conditions for recognition in a business combination (including Goodwill). The general assessment is that the survey results indicate a very low level of reporting practice of intangible assets in Serbia and relatively satisfactory level of reporting practice in Slovenia. Individual results are given in the fourth part of the paper.
\end{abstract}

Key words: Intangible assets, IFRS, Consolidated financial statements, Impairment test.

\section{НЕМАТЕРИЈАЛНА ИМОВИНА У КОНСОЛИДОВАНИМ \\ ФИНАНСИЈСКИМ ИЗВЕШТАЈИМА СРПСКИХ И СЛОВЕНАЧКИХ КОТИРАНИХ КОМПАНИЈА: ПРЕЛИМИНАРНИ ПРЕГЛЕД ПРАКСИ ИЗВЕШТАВАЊА}

\section{Апстракт}

Циљ овог истраживања је да се кроз компаративну дескриптивну анализу дође до закључака на ком је нивоу пракса извештавања о нематеријалној имовини у две посматране државе - у Републици Србији и Републици Словенији. Коришћени су консолидовани финансијски извештаји листираних компанија у ове две државе, и то са Београдске берзе (Србија) и Љубљанске берзе (Словенија). Разлог коришћења консолидованих финансијских извештаја лежи у чињеници да се у њима може наћи (неконсолидована) нематеријална имовина која је већ призната у појединачним 
финансијским извештајима компанија које чине групу, као и интерно генерисана нематеријална имовина која испуњава услове за признавање у пословној комбинацији (укључујући и гудвил). Општа је оцена да резултати истраживања указују на веома низак ниво праксе извештавања о нематеријалној имовини у Србији и релативно задовољавајући ниво извештавања у Словенији. Појединачни резултати дати су у четвртом делу рада.

Кључне речи: нематеријална имовина, МСФИ, консолидовани финансијски извештаји, тест обезвређења.

\section{INTRODUCTION}

Unlike the period of up to several decades ago, when the company value was based on the value of tangible assets, today's market shows that intangible assets have a dominant position in the value of both the largest and an increasing number of small companies. As a significant potential for a company's success, their recognition and proper valuation in financial statements ensures that users, especially investors, get relevant information for making investment and other decisions. A special challenge for accountants is the recognition of internally generated intangible assets, which, in accordance with the applicable accounting regulations, in most cases do not meet the conditions for recognition in separate financial statements. Since this part of intangible assets can be recognized in financial statements only after their market verification (either through merger or acquisition of another entity that has related intangible assets), consolidated financial statements are of particular importance. Specifically, in group financial statements there can be items of not only intangible assets previously recognized in separate statements of group members, but also of internally generated intangible assets of subsidiaries (companies invested in), for which the investor (parent company) paid additional amount above the fair value of existing net assets.

Practice of recognition and reporting of intangible assets, shown in a large number of studies, varies. The aim of this research is to, through a comparative and descriptive analysis, come to the conclusion on the level this practice has achieved in two countries - the Republic of Serbia and the Republic of Slovenia. Until two decades ago, both countries were an integral part of the common state and have some similarities with regard to the economic system in general and financial reporting systems, certainly with some differences related to specific regulatory environment, culture, and the like. The subject of the analysis focuses on consolidated financial statements disclosed by parent companies whose securities are traded on the Belgrade Stock Exchange (Serbia) and the Ljubljana Stock Exchange (Slovenia).

Bearing in mind the objective of the paper, the work is divided into four chapters. In addition to the introduction, the paper first indicates the 
importance of intangible assets and their reporting. Subsequently, the second part of the paper points to the basic requirements regarding reporting on intangible assets in accordance with IFRS (applied by the listed companies both in Serbia and Slovenia), with some specific challenges for the accounting profession in this regard. The third part presents the research design, i.e. research questions and sample. The fourth part of the paper gives the results of the research. Summarized conclusion is given afterwards.

\section{THE IMPORTANCE OF INTANGIBLE ASSETS FOR COMPANY PERFORMANCE AND CHALLENGES OF FINANCIAL REPORTING}

The company's competitive advantage is not realized only through its tangible assets, but, more and more, through its intangible resources (Andriessen, 2004; Greco et al., 2013; Mathur et al., 2007; Roxworthy et al., 2013). In addition, competitive advantage should not be a short-term goal, as the company is expected to achieve a sustainable advantage on the relevant market (Hall, 1993). The same author also emphasizes Coyne's opinion (1986), suggesting "that not only do the product and/or delivery system attributes need to be significant for customers, to be sustainable they also need to be the result of a capability differential which will endure" (Hall 1993, p. 610). These differentiated abilities are derived from the use of internally generated intangible assets. Intangible assets are also viewed as a key potential for value creation, "because their intangible charactermakes replication by competing firms considerably more difficult" (Roberts \& Dowling, 2002, p. 1077). In their study, these authors emphasize importance of reputation (which is primarily based on the brand of each company analyzed) for the stability of good business performance and overall competitive advantage. Specifically, based on the two models, autoregressive profit model and proportional hazards regression model, they confirm the hypothesis that companies with more superior performance have greater chances to maintain such performance over time if they have a relatively good reputation.

Intangible assets, unlike tangible assets, and, even often, financial assets, imply a higher risk for investors. In that sense, their non-recognition as part of the assets in the balance sheet, or non-disclosure of adequate information on their existence in the Notes to financial statements and in the Management Report, weakens the expressive power of these reports. On the other hand, the market indirectly verifies their existence, but only in the case when the company is listed on the stock exchange, through priceto-book ratio, while for closed-end companies, it is difficult to grasp the value of internally generated and in financial statements non-recognized intangible assets.

The challenges of conventional accounting particularly come to the fore when it comes to the recognition of internally generated intangible 
assets in financial statements. In essential conservative financial reporting, where rigid criteria for the recognition of some assets or liabilities are applied, a significant portion of internally generated intangible assets cannot be found in mandatory general-purpose statements. Therefore, an analysis of the company performance and its usefulness to decision-makers may be deficient, precisely because of the failure to take into account the value of intangible assets that remained outside the financial statements and (non)measurement of the effects of use of such assets. This problem is also present at the macro level, since the national statistics and aggregates derived from it are based on the financial statements of companies that operate in a particular branch or economy as a whole. Consequently, the assessment of the connection, for example, of investment in research and development or other elements of intangible investment, on the one hand, and economic growth, productivity, and similar indicators at the national economy level, on the other hand, has limited use value (van Ark \& Hulten, 2007).

Creating value in each company is the result of a large number of inputs and processes. Particular difficulties arise in the financial reporting on intellectual capital (Burgman \& Roos, 2007; Low et al., 2015; Guthrie et al., 2004; Sonnier, 2008; Radić, 2016). Intellectual capital is one of the intangible resources that can decisively affect the results whose volatility in many cases is unpredictable, with reversed interdependence also present. Specifically, "the inability to predict nonlinear, dynamical outcomes has another practical implication on related accounting theories and approaches: there are no certain formulas or principles available on how best to create intelectual capital“ (Niculita et al., 2012, p. 307). Difficulties regarding the recognition of intellectual capital also arise from its heterogeneity (human, structural, and relational capital). Since accounting theory and practice have not yet provided generally accepted guidelines for the recognition of intellectual capital in general-purpose financial statements, this paper will not deal with this category of intangible assets.

\section{SPECIFICS AND IMPLICATIONS OF RECOGNITION AND VALUATION OF INTERNALLY GENERATED INTANGIBLE ASSETS ACQUIRED IN BUSINESS COMBINATIONS}

Guidelines for resolving the issue of recognition and valuation of intangible assets are contained in applicable accounting standards, primarily IAS 38 - Intangible assets and IFRS 3 - Business Combinations, i.e. in national regulations where IFRS are not applied. Most of the internally generated intangible assets (except, for example, software, certain R\&D costs) remain outside separate financial statements due to non-compliance with the recognition requirements. This part of intangible assets can only be recognized in a business combination when the payment by the acquirer results in their market verification. The accounting procedure applied in this 
way is based on the applic ation of the acquisition method in accordance with IFRS 3.

According to this method, the acquirer should, on the date of acquisition, allocate the amount of consideration transferred to recognizable assets, liabilities, and contingent liabilities at fair value through recognition of goodwill (for the remaining unallocated amount) or a gain from favorable purchase. Bearing in mind that the realization of each business combination extends over a longer period of time and that completion of all relevant information related to acquired assets and liabilities cannot happen until the moment when the first consolidated financial statement of the acquirer is made, "PPA - Purchase Price Alloc ation is globally divided in two phases pre-phase and main phase" (Arbeitskreis, 2009, p. 7). In this regard, the entire methodology of the PPA consists of: (1) defining the PPA strategy, then (2) analyzing the transactions, followed by (3) implementing the PPA, and finally, (4) disclosure (Vettiger \& Hirzel, 2009, p. 75-108).

Recognition of acquired assets and assumed liabilities and their measurement on the acquisition date is, for example, of an indicative character, since IFRS 3 (rev. 2008), in paragraphs 45-50, allows the acquirer within the next 12 months to retroactively adjust the preliminary amounts recognized on the date of acquisition and to possibly recognize additional assets and liabilities if they obtain information about the facts and circumstances that on the date of acquisition existed as the basis for their recognition. "Adjusting a pre-recognized amount of assets and liabilities will result in an increase or decrease in the initially recognized goodwill" (Spasić, 2012, p. 143). Adjustments should be made in accordance with IAS 8 , by retroactively adjusting the initial inclusion of a business combination on the date of acquisition.

Therefore, the acquirer in the business combination must first identify the existence of certain internally generated intangible assets of the acquired company using certain techniques (see: Rogler et al., 2014; Spasić, 2012, p. $142-145$, etc.), and then determine whether the conditions for recognition in accordance with IAS 38 have been met. Pursuant to the said standard, in order for an intangible asset to be recognized, it must satisfy the separability criterion or the contractual-legal criterion- the main features of its recognition. As recognizable intangible assets acquired in a business combination separate from goodwill, the following can be recognized: brand, internet domain name, packaging, new spaper masthead (marketing-related intangible assets), customer lists, outstanding orders, customer contracts and related customer relationships (customer-related intangible assets),plays, opera, ballet, books, musical works, paintings (artist-related intangible assets), franchise agreements, licensing agreements, construction agreements, use rights (contract-based intangible assets), patented and non-patented technology, computer software, databases, craft secrets (technology-based intangible assets), and others (IFRS 3 - Illustrative examples). 
The procedure described above briefly suggests that there are many areas of this process that can affect the amount of goodwill/gain from favorable purchase presented, but also the entire consolidated financial statement. First, the determination of the fair value of not only consideration transferred, but also the acquired assets and liabilities assumed, including internally generated intangible assets that meet the conditions for recognition separately from goodwill in the financial statement of the acquirer, and the offered options for determining that fair value, give rise to information in the financial statements no longer being based on the prudence principle, i.e. reports could be characterized as "imprudent per se" (André et al., 2015, p. 483). In fact, there is a danger that managers use the PPAprocess for the purpose of managing the result, through a conscious recognition of a larger amount of goodwill on the basis of underestimating the fair value of the acquired net assets (or vice versa). In other words, there is a danger that non-objective or unjustified recognition of hidden reserves (as well as hidden losses) contained in the value of the acquired assets and assumed liabilities can be used to manipulate the amount of goodwill and future performance of the combined entity (Brähler \& Schmidt, 2014, p. 1075). This is confirmed in the study of about 300 acquisitions, stating that managers whose earnings depend on the achieved result have a tendency to recognize a greater amount of goodwill (Shalev et al., 2013).

\section{RESEARCH DESIGN AND SAMPLE SELECTION}

\section{Research Design}

In order to investigate the extent to which the listed companies in Serbia and Slovenia recognize intangible assets and report them in consolidated financial statements, for initial insight, descriptive statistics is used. The analysis focuses on three research questions:

RQ 1 What is the level and frequency of recognition of intangible assets, as well as their structure?

RQ 2 What is the level of disclosure about the nature of business combinations?

RQ 3 What is the treatment of goodwill and other intangible assets acquired in a business combination and disclosure in connection therewith?

RQ 1 - Given that, as already pointed out, intangible assets in consolidated financial statements can comprise two components: (1) intangible assets already recognized in separate financial statements of group members (not subject to consolidation); and (2) internally generated intangible assets of dependent entities acquired and market verified through payment by the investor (parent company), we investigated the tendency to recognize total intangible assets, as well as other components. Within the 
second component, further research focuses on whether and how often intangible assets are recognized separately from goodwill.

While recognition of unconsolidated intangible assets arising from separate financial statements is not called into question, the recognition of goodwill and recognizable intangible assets acquired in a business combination is subject to possible manipulation. In fact, the recognition of a larger amount of goodwill (the so-called abnormal goodwill Paugam et al., 2015) must not be unconditionally connected with the underestimation of the fair value of the acquired net assets, but also with the non-recognition of recognizable internally generated intangible assets that meet the requirements for recognition separately from goodwill. Direct impact on future results based on this "redistribution" of surplus payments in the acquisition (control) transaction of net assets is reflected in subsequent valuation. Specifically, while intangible assets (which, in principle, have a limited use life), recognized separately from goodwill, must be depreciated on a systematic basis, goodwill is subject to an impairment test, the outcome of which may not necessarily lead to periodic write-off and recognition of expenses. In addition, recognizable identifiable intangible assets are an additional management challenge, given their relevance for the definition of strategies, development of new products/services, and the like. Often, some intangible assets (e.g. brand, relationships with customers, etc.) are not valued only in monetary terms, but the final value is influenced by assessment of qualitative features, attitudes, preferences, etc. This certainly leaves room for subjectivism in assessment, on the one hand, but, on the other hand, looking at nonfinancial indicators in valuation can also strengthen the importance and ability to manage related intangible assets (Günther's discussion, cited according to: Knappstein \& Schmeling, 2014, p. 339).

RQ 2 -To understand the nature of goodwill and intangible assets recognized separately from goodwill in a business combination, it is necessary to disclose relevant information in Notes to financial statements - primarily on the business combination itself, the amount of the transferred consideration, and fair value of the acquired net assets. It is considered that the absence of these disclosures may result in "plenty of room for a targeted accounting policy and the conscious shaping of the balance sheet, income statement, and cash flows" (Spasić, 2012, p. 146), since no recognition of goodwill and intangible assets acquired in a business combination may be the result of a deliberate approximation of the value of the factors that affect their amount.

RQ 3 - The significance of analysis of how the recognized goodwill and intangible assets recognized separately from goodwill is valued subsequently lies in the fact that, particularly when it comes to recognized goodwill, management can significantly affect the reported performance of the reporting entity. The current IFRS 3 and IAS 38 guidelines abandoned the amortization of goodwill on a systematic basis 
and instead test it at the level of the cash-generating unit. Referring to the essence of the process of testing goodwill impairment, the key areas of excessive management discretion are usually: (1) allocation of goodwill to cash-generating units; (2) calculation of the recoverable amount; as well as from the standpoint of IFRS 3 prescribed (3) concept of "impairment-only approach" and the related issue of the justification of such exclusivity (Gundel et al., 2014, pp. 132-133).

Due to its sensitivity, for all activities in the specified areas of the impairment test, it is expected that the information presented to investors is relevant and credible. However, many empirical studies show precisely that conducting a goodwill impairment test is a valuable management tool, which is why the expressive power of information about goodwill, as well as performance indic ators must be carefully weighed. On the one hand, goodwill impairment is viewed essentially as recognition of the failure to maintain the value of prior acquisition, since its impairment is a signal that the acquisition was overpaid (Filip et al., 2015, p. 522). On the other hand, managers postpone recognition of goodwill impairment to avoid disclosing the negative result of the current period, thereby protecting their reputation, avoiding constraints by creditors (including initiating bankruptcy) in accordance with defined debt-covenants, and, ultimately, for personal gain.

In addition to the postponement strategy, managers also use the possibility of excessive recognition of goodwill amortization for the socalled "big-bath accounting". The use of this "discretion makes it difficult for users of financial statements to get a true picture of the financial situation and performance of the reporting entity. Consequently, comparison with other entities is difficult, which ultimately leads to a lack of transparency in the annual report" (Rogler, Straub and Tettenborn, cited according to: Kümpel \& Klopper, 2014, p. 185). Hence the need for a careful interpretation of both expense based on goodwill amortization in the year when they are recognized in the Annual Report and the amount of the goodwill itself, but not only for this accounting period, but also in the analysis of the achieved performance in the years when there is no impairment.

\section{Sample Selection}

In order to realize the objective of this paper, in accordance with the defined research questions, the sample consists of consolidated financial reports submitted by parent companies whose shares are traded on organized capital markets in Serbia (the Belgrade Stock Exchange) and in Slovenia (the Ljubljana Stock Exchange). Both capital markets are small in size, which is why all listed companies in the industry are included in the sample, while banks, insurance companies, and other financial organizations have not been taken into consideration due to the specific nature of operations and different financial statements. The 
sample, therefore, consists of consolidated financial statements of 16 companies on the Belgrade Stock Exchange and 11 companies on the Ljubljana Stock Exchange. The companies included in the sample come from all segments of the stated capital markets (Prime, Standard, and Open market). It should be noted that in the analyzed period some companies changed the segment within which they were listed. The analysis was carried out based on consolidated financial statements in the defined sample for the three-year period, i.e. from 2014-2016. This means that the total potential sample was 81 consolidated financial statements (48 from Serbia and 33 from Slovenia). Given that the two companies from the Ljubljana Stock Exchange were delisted during 2016 due to the change in legal status (fusion with another company), there are no disclosed consolidated financial statements for 2016 for these companies.

Therefore, the final sample is defined based on 79 consolidated financial statements (48 from the Belgrade Stock Exchange and 31 from the Ljubljana Stock Exchange) for the period 2014-2016.

Although the number of consolidated financial reports included in the sample is not large, the sample is considered to be representative, since all the entities included submit reports for their group on analyzed capital markets.

\section{RESULTS}

Level and Frequency of Recognition of Intangible Assets and Structure of Intangible Assets (RQ 1)

The trend of increased significance of intangible assets as the resources of each company, and also the group, visible in the analysis of consolidated and separate financial reports in developed market economies, in the case of Serbia and, to a certain extent, Slovenia, is not present. This is seen in Table 1:

Table 1. Share of intangible assets in total assets and fixed assets

\begin{tabular}{|c|c|c|c|c|c|c|c|}
\hline \multirow{3}{*}{$\begin{array}{l}\text { Share of intangible } \\
\text { assets in } \%\end{array}$} & \multicolumn{7}{|c|}{$\begin{array}{l}\text { Share of intangible as sets in Share of intangible as sets in } \\
\text { total assets of the group total non-current assets }\end{array}$} \\
\hline & Serbia & \multicolumn{2}{|c|}{ Slovenia } & \multicolumn{2}{|c|}{ Serbia } & \multicolumn{2}{|c|}{ Slovenia } \\
\hline & $\mathrm{n} \quad \%$ & $\mathrm{n}$ & $\%$ & $\mathrm{n}$ & $\%$ & $\mathrm{n}$ & $\%$ \\
\hline $0 \%$ & $36.25 \%$ & - & - & 3 & $6.25 \%$ & - & \\
\hline $0.01-0.99 \%$ & $3470.83 \%$ & 10 & $32.26 \%$ & 26 & $54.16 \%$ & 9 & $29.03 \%$ \\
\hline $1.00-4.99 \%$ & $612.50 \%$ & 7 & $22.58 \%$ & 11 & $22.92 \%$ & 7 & $22.58 \%$ \\
\hline $5.00-9.99 \%$ & $510.42 \%$ & 4 & $12.90 \%$ & 8 & $16.67 \%$ & 1 & $3.23 \%$ \\
\hline $10.00-19.99 \%$ & - $\quad-$ & 9 & $29.03 \%$ & - & - & 8 & $25.81 \%$ \\
\hline $20.00-29.99 \%$ & - & 1 & $3.23 \%$ & - & - & 2 & $6.45 \%$ \\
\hline More than $30.00 \%$ & - & - & - & - & - & 4 & $12.90 \%$ \\
\hline Total & 48 & 31 & & 48 & & 31 & \\
\hline
\end{tabular}


Based on the data presented, it is obvious that intangible assets in the consolidated financial statements of listed companies from Serbia are materially insignificant items. On the other hand, Slovenian companies use to a much greater extent the possibility of recognizing this assets item, which is shown by data on its share in total assets and fixed assets of groups whose consolidated financial statements have been analyzed.

Since intangible assets in consolidated financial statements can consist of items exclusively derived from a business combination and items already recognized in separate financial statements, Table 2 gives the results of the structure of recognized and disclosed intangible assets in the analyzed sample.

Table 2. Structure of recognized intangible assets in the sample

\begin{tabular}{|c|c|c|c|}
\hline & & Serbia & Slovenia \\
\hline & & $\%$ & $\mathrm{n} \quad \%$ \\
\hline I. & $\begin{array}{l}\text { Intangible as sets recognized in the } \\
\text { business combination }\end{array}$ & $10 \quad 20.83 \%$ & $26 \quad 83.87 \%$ \\
\hline & 1. Goodwill & 10 & 20 \\
\hline & $\begin{array}{l}\text { 2. Internally generated intangible } \\
\text { as sets acquired in a business } \\
\text { combination - recognized as a } \\
\text { separate item }\end{array}$ & & \\
\hline & $\begin{array}{l}\text { 2.1. Intangible as sets recognized } \\
\text { with recognition of goodwill }\end{array}$ & 0 & 14 \\
\hline & $\begin{array}{l}\text { 2.2. Recognized intangible assets } \\
\text { without recognition of } \\
\text { goodwill }\end{array}$ & 0 & 6 \\
\hline II. & $\begin{array}{l}\text { Intangible as sets recognized before } \\
\text { business combination (in separate } \\
\text { financial statements) }\end{array}$ & $45 \quad 93.75 \%$ & $100 \%$ \\
\hline III. & $\begin{array}{l}\text { Intangible as sets in consolidated financial } \\
\text { statements }=0\end{array}$ & $6.25 \%$ & $\mathbf{0}$ \\
\hline
\end{tabular}

Observed by the origin of intangible assets, comparative analysis shows that Slovenian companies dominantly recognize intangible assets acquired in business combination (83.87\%), as opposed to the low level of recognition in listed companies in Serbia (20.83\%). So, one case from the Slovenian sample recognized profit from favorable purchase, while in the Serbian sample there was no such outcome.

Although the fact that $79.17 \%$ of the sample in Serbia did not recognize either goodwill or gain from favorable purchase is certainly unexpected, research conducted in other countries indic ates the existence of similar results. For example, in 308 analyzed acquisitions in Australia in the period from 1998-2012 it was established that, even in $42 \%$ of 
cases, neither positive nor negative difference was established (Buge \& Loyeung, 2015). The authors interpret the equivalence of the fair value of the consideration transferred and the fair value of the net assets acquired as a consequence of the managers' inclination to avoid a complex and, in terms of costs, demanding procedure for the allocation of the consideration transferred, which could be the reason for the analysis result of the initial sample in the Republic of Serbia. Additionally, however, the reason for not recognizing goodwill and other intangible assets acquired in a business combination may be the fact that parent companies in Serbia predominantly own $100 \%$ of dependent entities they established themselves. On the other hand, business combinations in Slovenia are more often carried out with the payment of a larger amount by the acquirer to acquire control over the capital of the dependent entities $(83.87 \%$, i.e. 26 out of 31 cases, or, when it comes to the recognition of goodwill $64.52 \%$, i.e. 20 out of 31 cases).

Unlike the practice of allocating consideration transferred in developed economies, it is notic eable that, in a sample of Serbian companies, in none of the goodwill recognition cases there was separate recognition of recognizable intangible assets ( 0 out of 10 ). Specifically, according to the European Securities and Markets Authority (ESMA), in an average of $76 \%$ of cases of analyzed business combinations, acquired intangible assets are recognized separately from goodwill (ESMA, 2014, par. 61). On the other hand, Slovenian companies recognize recognizable intangible assets acquired in a business combination separately from goodwill at the level close to the European average (70\%, i.e. 14 out of 20 ), but also recognize exclusively internally generated intangible assets without recognizing goodwill $(23 \%$, i.e. 6 out of 26). In the first case, separately from goodwill, Slovenian companies most often recognize brand as recognizable intangible assets acquired in a business combination.

It should be noted that, in the case of non-consolidated intangible assets already recognized in separate financial statements of group companies, software occupies a dominant position, followed by costs of research and development that meet the condition for recognition. In fewer cases, concessions and similar rights are recognized.

\section{The Level of Disclosure about the Nature of Business Combinations (RQ 2)}

Knowing the circumstances under which a business combination is carried out is also important for users of financial statements. In addition to the narrative description, in order to assess the justification of recognition of goodwill, recognizable intangible assets separate from goodwill, or gain from favorable purchases, information on the consideration transferred itself in the valuation of acquired net assets is also important. 
Table 3. Disclosure of the initial recognition and valuation of goodwill

\begin{tabular}{|c|c|c|c|c|c|c|c|c|}
\hline \multirow{3}{*}{$\begin{array}{l}\text { No. Dis closures made in Notes } \\
\text { to Cons olidated Financial } \\
\text { Statements }\end{array}$} & \multicolumn{4}{|c|}{ Serbia } & \multicolumn{4}{|c|}{ Slovenia } \\
\hline & \multicolumn{2}{|c|}{ YES } & \multicolumn{2}{|c|}{$\mathrm{NO}$} & \multicolumn{2}{|r|}{ YES } & \multicolumn{2}{|c|}{ NO } \\
\hline & $\mathrm{n}$ & $\%$ & $\mathrm{n}$ & $\%$ & & $\mathrm{n}$ & $\%$ & \\
\hline $\begin{array}{l}\text { 1. Description of previous } \\
\text { acquisitions }\end{array}$ & & $8.75 \%$ & 39 & $81.25 \%$ & $\overline{15}$ & $48.39 \%$ & 165 & $1.61 \%$ \\
\hline $\begin{array}{l}\text { 2. Description of acquisitions } \\
\text { in the current reporting } \\
\text { period } \\
\text { For acquisitions in the } \\
\text { current reporting period }\end{array}$ & 0 & - & 4 & $100 \%$ & 6 & $100 \%$ & 0 & - \\
\hline $\begin{array}{l}\text { 3. Fair value of the } \\
\text { considerationtransferred }\end{array}$ & 1 & $25 \%$ & 3 & $25 \%$ & 3 & $50 \%$ & 3 & $50 \%$ \\
\hline $\begin{array}{l}\text { 4. Fair value of acquired net } \\
\text { assets }\end{array}$ & 1 & $25 \%$ & 3 & $25 \%$ & 3 & $50 \%$ & 3 & $50 \%$ \\
\hline
\end{tabular}

Unlike the European average (82\% - ESMA, 2014, par 21), only every fifth business combination achieved in the previous period is described in the notes to financial statements of parent entities listed on the Belgrade Stock Exchange. However, in no case of acquiring a dependent entity in the current year in which the consolidated financial statement has been analyzed is there more detailed description of the business combination. This deficiency is partly compensated only in one case of acquisition, where the fair value of the consideration transferred and the fair value of the acquired net assets of the controlled entity are disclosed.

On the other hand, companies on the Ljubljana Stock Exchange disclose significantly more information on the nature of acquisition, as well as the amount of determinants that influenced goodwill recognition (or gain from favorable purchase) in their Notes. However, the level of these disclosures of $50 \%$ is signific antly lower than the average determined in the ESMA study, not only when it comes to the description of the business combination, but also the disclosure of the amount of the paid acquisition price and the associated net assets (for example, ESMA analysis states that in $92 \%$ of cases the fair value of the acquired assets and assumed liabilities was disclosed).

Treatment of Goodwill and Other Intangible Assets Acquired in Business Combination and Disclosure in Connection with it (RQ 3)

As pointed out in the definition of the third research question (RQ 3), intangible assets (including goodwill) recognized in a business combination are a management tool to manage the future result. For this very reason, we analyzed how often the impairment test is being 
conducted, whether and to what extent this procedure leads to the recognition of impairment losses, and disclosures in connection with this procedure in the Notes that the parent entities on the Serbian and Slovenian capital markets publish for their group. Some results are given in Table 4.

Table 4. Disclosures on the subsequent valuation of goodwill

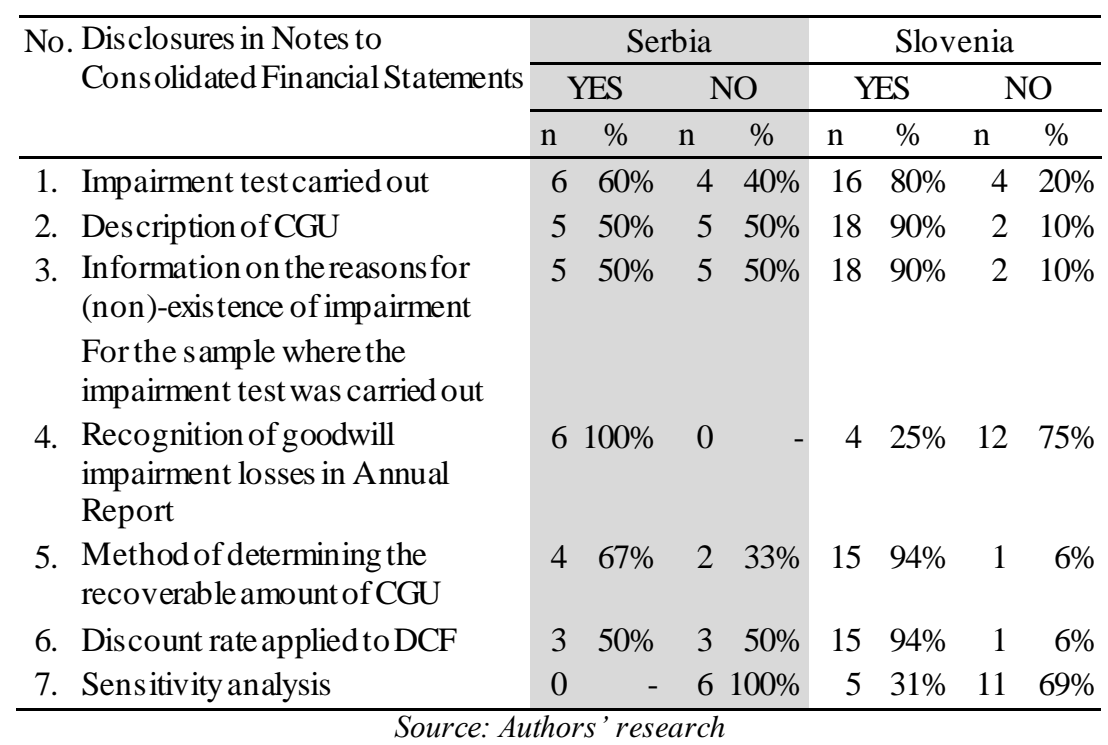

Table 2 shows that recognized goodwill was found in 10 consolidated financial statements on the Belgrade Stock Exchange and 20 group statements on the Ljubljana Stock Exchange. Similar to previous research questions, the listed companies in Serbia, when it comes to treating goodwill after initial recognition, disclose a smaller amount of information than listed companies in Slovenia.

It can be concluded that the "impairment test exclusively" model is not fully accepted in the practice of subsequent goodwill valuation in the financial reporting of groups on the Serbian and Slovenian capital markets. In the companies that make up our sample, this option was used to avoid recognition of goodwill impairment losses. This applies in particular to parent companies listed on the Ljubljana Stock Exchange, where each fourth group, in whose financial statements there is goodwill, recognized the impairment loss. However, such a phenomenon is not immanent only for the companies that are the subject of our research, but also beyond. In fact, in its 2013 report, ESMA found that only 36\% of cases recognized goodwill impairment loss (ESMA, 2013, par. 32). It should be noted that the data on the recognition of goodwill impairment 
loss in the Serbian sample should be taken with reserve. Specifically, our research has shown that, in some cases, items that should show the actual goodwill impairment disclose other expenses not related to goodwill, and some cases recognized goodwill impairment losses even contrary to the guidelines of accounting regulations.

Investors and other users of consolidated financial statements attach importance not only to information whether and to what extent goodwill has been impaired, but also on the way impairment has been established. Disclosures on how to determine the recoverable amount of $67 \%$ in Serbia and 94\% in Slovenia are quite satisfactory, with Slovenian companies being at the average European level (92\% - ESMA, 2013, par. 38). Transparent reporting on the impairment test methodology is present in companies listed on the Ljubljana Stock Exchange, since in $94 \%$ of cases they report on the discount rate used in assessing the DCF value of CGU (66\% in Europe - ESMA, 2013, par. 47). Since the impairment test model requires the introduction of numerous assumptions in determining the recoverable amount, an additional sensitivity analysis is of particular importance for assessing the reality of the conducted test. In the analyzed sample, we found that Serbian companies did not disclose in any case whether they performed the sensitivity analysis, while in the sample of Slovenian companies, this disclosure was done for every third conducted goodwill impairment test.

\section{CONCLUSION}

Reporting on intangible assets at the group level is of particular importance to investors, since the consolidated financial statements also show the part of internally generated intangible assets acquired in a business combination, which cannot otherwise be recognized in separate financial statements. As an important potential of the company's profitability and its value on the capital market, reporting on intangible assets is gaining in importance. In this paper, we pointed out certain issues related to the accounting treatment of goodwill and other intangible assets, and the reporting practice in relation to this in two countries -in Serbia and Slovenia.

From the theoretical and normative point of view, one of the most controversial issues is the introduction of the "impairment test exclusively" concept for goodwill recognized in a business combination. Bearing in mind the possible consequences of the application of this concept, literature and practice increasingly discuss the (non)-justification of abandonment of classical goodwill amortization. It is justifiable to ask whether occasional, i.e. irregular (often at the managers' request), goodwill write-off is in accordance with one of the basic principles of determining the periodic result, or the principle of causation (Protzek, 
2003, p. 497). Studies by van Hulzen et al. (2012) "show that the amortization expense on goodwill is more value relevant than the impairment expense. This indicates that investors perceive the amortization expense as more relevant information for investment decision and stock price valuation". The criticism of using the impairment test exclusively concept seems justified, and, therefore, we consider that it would be more expedient to restore the required amortization on a systematic basis, with a periodic impairment test, as a corrector of possible misstatements of the useful life of goodwill and the write-off method. In addition, such a solution would also serve to compare financial statements prepared in accordance with IFRS for small and medium-sized entities.

By analyzing the consolidated financial statements of listed companies on the Belgrade Stock Exchange and the Ljubljana Stock Exchange, we established a very low level of reporting practice on intangible assets, especially in Serbian companies. The fact that out of the 48 analyzed consolidated financial statements of the entities listed on the Belgrade Stock Exchange only in 10 cases there is recognized goodwill from business combination, and that there is a low level of disclosure transparency in this regard, confirms the conclusion about the low expressive power of these reports for investors and the necessity of improvement in the field of financial reporting on intangible assets on the Serbian capital market.

On the other hand, Slovenian companies pay much more attention to reporting on intangible assets. In addition to the recognition of goodwill and other intangible assets acquired in the business combination, in the sample from the Ljubljana Stock Exchange, the level of disclosure in relation to the method of initial valuation of intangible assets acquired in the business combination is also high, as well as the subsequent valuation of goodwill.

\section{REFERENCES}

André, P., Filip, A.\& Paugam, L. (2015). The Effect of Mandatory IFRS Adoption on Conditional Conservativism in Europe. Journal of Business Finance \& Accounting, 42(3-4), 482-514.

Andriessen, D. (2004). IC valuation and measurement: classifying the state of the art. Journal of Intelectual Capital, 5(2), 230-242. doi:10.1108/14691930410533669.

Arbeitskreis „Immaterielle Werte im Rechnungswesen“ der Schmalenbach-Gesellschaft für Betriebswirtschaft e.V. (2009). Immaterielle Werte im Rahmen der Purchase Price Allocation bei Unternehmenszusammenschlüssen nach IFRS - Ein Beitrag zur Best Practice [Intangible assets i the context of the purchase price allocation in business combinations according to IFRS - A contribution to best practice]. $Z f B F$ Sonderheft 60/09, herausgegeben von Axel Haller und Rüdiger Reinke, Düsseldorf

Brähler, G. \& Schmidt, S. (2014). Hidden Reserves Under IFRS - Empirical Insight. International Review of Management and Business Research, 3(2), 1073-1086.

Bugeja, M.\& Loyeung, A. (2015). What drives the allocation of the purchase price to goodwill?. Journal of Contemporary Accounting \&Economics, 11(3), 245-261. 
Burgman, R. \& Roos, G. (2007). The importance of intellectual capital reporting: evidence and implications. Journal of Intellectual Capital, 8(1), 7-51. doi:10.1108/14691930710715051.

ESMA. (2013). ESMA Report. European enforcersreview of impairment of goodwill and other intangible assets in the IFRS financial statements. Retrieved from:https://www.esma.europa.eu/sites/default/files/library/2015/11/201302.pdf

ESMA. (2014). ESMA Report. Review on the application of accounting requirements for business combinations in IFRS financial statements. Retrieved from:https://www.esma.europa.eu/sites/default/files/library/2015/11/2014643_esma_report_on_the_ifrs_3.pdf.

Filip, A., Jeanjean, T. \& Paugam, L. (2015). Using Real Activities to Avoid Goodwill Impairment Losses: Evidence and Effect on Future Performance. Journal of Business Finance \& Accounting, 42(3-4), 515-554.

Greco, M., Cricelli, L. \& Grimaldi, M. (2013). A strategic management framework of tangible and intangible assets. European Management Journal, 31(1), 55-66. doi:10.1016/j.emj.2012.10.005.

Gundel, T., Möhlmann-Mahlau, T., Sündermann, F. (2014). Wider dem ImpairmentOnly-Approach oder die Goodwillblase wächst [Against the impairment-only approach or the goodwill bubble grows]. KoR - Zeitschrift für internationale und kapitalmarktorientierte Rechnungslegung, 14(3), 130-137.

Guthrie, J., Petty, R. \& Yongvanich, K. (2004). Using content analy sis as a research method to inquire into intellectual capital reporting. Journal of Intelectual Capital, 5(2), 282-293.doi:10.1108/14691930410533704.

Hall, R. (1993). A framework linking intangible resources and capabilities to sustainable competitive advantage. Strategic Management Journal, 14(8), 607-618. doi: $10.1002 / \mathrm{smj} .4250140804$.

Knappstein, J. \& Schmeling, A.K. (2014). Immaterielle Ressourcen und Innovationen: Herausforderungen für Management, Rechnungswesen und Marketing Bericht über die Schmalenbach-Tagung 2014 in Köln [Intangible resources and innovation: Challenges for management, accounting and marketing - A Report on the Schmalenbach Conference 2014 in Cologne]. KoR - Zeitschrift für internationale und kapitalmarktorientierte Rechnungslegung, 14(6), 332-340.

Kümpel, T., Klopper, T. (2014). Goodwill Impairment-Test nach IFRS - eine Analy se des DAX30 (Teil 2) [Goodwill impairment test according to IFRS - an analysis of the DAX 30 (Part 2)]. KoR - Zeitschrift für internationale und kapitalmarktorientierte Rechnungslegung, 14(4), 177-185.

Low, M., Samkin, G. \& Li, Y. (2015). Voluntary reporting of intellectual capital: Comparing the quality of disclosures from New Zealand, Australian and United Kingdom univesities. Journal of Intellectual Capital, 16(4), 779-808. doi:10.1108/JIC-03-2015-0022.

Mathur, G., Jugdev, K. \& Fung, T.S. (2007). Intangible project management assets as determinants of competitive advantage. Management Research News, 30(7), 460-475. doi:10.1108/01409170710759694.

Niculita, A.L., Popaa, A.F. \& Caloiana, F. (2012). The Intangible Assets: A New Dimension of The Company's Success. Procedia Economic and Finance, No. 3, Elsevier, 304-308.

Paugam, L., Astolfi, P. \& Ramond, O. (2015). Accounting for business combinations: Do purchase price allocations matter?. Journal of Accounting and Public Policy, 34(4), 362-391.

Protzek, H. (2003). Der Impairment Only-Ansatz - Wider der Vernunft [The Impairment Only Approach - Against Reason]. KoR - Zeitschrift für internationale und kapitalmarktorientierte Rechnungslegung, 3(11), 490-495. 
Radić, S. (2016). Vrednovanje intelektualnog kapitala primenom metode obračunate nematerijalne vrednosti [Measurement of Intellectual Capital using Calculated Intangible Value Method]. Ekonomske ideje i praksa, No. 22, 71-88.

Roberts, P.W. \& Dowling, G.R. (2002). Corporate Reputation and Sustained Superior Financial Performance. Strategic Management Journal, 23(12), 1077-1093. doi:10.1002/smj.274.

Rogler, S., Schmidt, M.\& Tettenborn,M . (2014). Ansatz immaterieller Vermögenswerte bei Unternehmenszusammenschlüssen [Recognition of intangible assets in business combinations]. KoR - Zeitschrift für internationale und kapitalmarktorientierte Rechnungslegung, 14(12), 577-585.

Roxwothy, P., Atkinson, R., Beran, R. \& van Ark, B. (2013). Competitive advantage: the importance of intangible assets to U.S. economic growth in the global economy. Taxes: The Tax Magazine, 91(6), 13-22.

Shalev, R., Zhang, I.X. \& Zhang, Y. (2013). CEO Compensation and Fair Value Accounting: Evidence from Purchase Price Allocation. Journal of Accounting Research, 51(4), 819-854.

Sonnier, B.M. (2008). Intellectual capital disclosure: High-tech versus traditional sector companies. Journal of Intellectual Capital, 9(4), 705-722.

Spasić, D. (2012). Nematerijalna imovina povezana sa kupcima - priznavanje i vrednovanje u poslovnoj kombinaciji odvojeno od gudvila [Customer-related intangible assets: Recognition and measurement separately from goowill in business combination]. Marketing, 43(2), 141-156. doi:10.5937/markt.1202141S.

van Ark, B. \& Hulten, C. (2007). Innovation, Intangibles and Economic Growth: Towards a Comprehensive Accounting of Knowledge Economy. (Economic Program Working Paper Series EPWP \#07-02). New York: The Conference Board Economic Program.

van Hulzen, P., Alfonso, L., Goergakopoulos, G. \& Sotiropoulos, I. (2011). Amortisation Versus Impairment of Goodwill and Accounting Quality. International Journal of Economic Sciences and Anplied Research, 4(3), 93118, Available at SSRN: https://ssrn.com/abstract=1978895.

Vettiger, T.\& Hirzel, C. (2009). Praktische Umsetzung der IFRS-Richtlinien zu Unternehmenskäufen [Practical implementation of IFRS guidelines for company acquisitions]. Finanz- und Rechnungswesen, Jahrbuch 2009, 75108. Zürich: Weka

\title{
НЕМАТЕРИЈАЛНА ИМОВИНА У КОНСОЛИДОВАНИМ ФИНАНСИЈСКИМ ИЗВЕШТАЈИМА СРПСКИХ И СЛОВЕНАЧКИХ КОТИРАНИХ КОМПАНИЈА: ПРЕЛИМИНАРНИ ПРЕГЛЕД ПРАКСИ ИЗВЕШ ТАВАЊА
}

\author{
Дејан Спасић, ${ }^{1}$ Антон Ворина ${ }^{2}$ \\ ${ }^{1}$ Универзитет у Нишу, Економски факултет, Ниш, Србија \\ ${ }^{2}$ Економска школа, Виша стру ковна школа, Цеље, Словенија
}

\section{Резиме}

Нематеријална имовина представља један од најважнијих ресурса у савременим условима пословања. Као значајан потенцијал успеха за компанију, њено признавање и правилно вредновање у финансијским извештајима доприноси 
томе да корисници, а нарочито инвеститори, буду снабдевени релевантним информацијама за доношење инвестиционих и других одлука. Посебан изазов за рачуноводствену професију представља признавање интерно генерисане нематеријалне имовине, која сходно важећој рачуноводственој регулативи, у највећем броју случајева не испуњава услове за признавање у појединачним финансијским извештајима. Будући да се овај део нематеријалне имовине може признати у финансијским извештајима тек након њене тржишне верификације (било кроз припајање или стицање контроле над другим ентитетом који поседује односну нематеријалну имовину), посебан значај добијају консолидовани финансијски извештаји.

Циљ нашег истраживања је да кроз компаративну дескриптивну анализу дођемо до закључака на ком је нивоу ова пракса у две посматране државе - у Републици Србији и Републици Словенији. Обе државе су до пре две деценије биле саставни део заједничке државе и поседују одређене сличности у погледу економског система уопште и система финансијског извештавања, свакако уз постојање разлика везаних за специфичности регулаторног окружења, културе и сл. Предмет анализе су консолидовани финансијски извештаји које обелодањују матични ентитети чијим се власничким хартијама од вредности тргује на Београдској берзи (Србија) и Љубљанској берзи (Словенија).

Иако број консолидованих финансијских извештаја укључених у узорак није велики (48 извештаја са Београдске берзе и 31 извештај са Љубљанске берзе за период 2014-2016. године), узорак сматрамо репр езентативним, будући да се ради о свим ентитетима који подносе извештаје за своју групу на анализираним тржиштима капитала. Такође, репрезентативност узорка може се тумачити и чињеницом да се јавним друштвима, сагласно захтевима Берзе и Закона о тржишту капитала, постављају већи захтеви за објављивањем информација и, по природи ствари, као „отворена”, она су заинтересована да постојећим и потенцијалним инвеститорима пруже релевантне и веродостојне информације - у нашем случају о нематеријалној имовини.

Резултати истраживања показују веома низак ниво праксе извештавања о нематеријалној имовини, нарочито српских компанија. Чињеница да од 48 анализираних консолидованих финансијских извештаја ентитета који се листирају на Београдској берзи само у 10 случајева је признат гудвил из пословне комбинације и да у вези са тим постоји низак ниво транспарентности обелодањивања - потврђује закључак о ниској исказној моћи ових извештаја за инвеститоре и о неопходности побољшања у сфери финансијског извештавања о нематеријалној имовини на српском тржишту капитала.

$\mathrm{Ca}$ друге стране, словеначке компаније много више пажње посвећују извештавању о нематеријалној имовини. Осим што се чешће признаје гудвил и остала нематеријална имовина стечена у пословној комбинацији, висок је ниво обелодањивања у вези са начином почетног одмеравања нематеријалне имовине стечене у пословној комбинацији, али и накнадног вредновања гудвила у узорку са Љубљанске берзе. 